\title{
The Effects of Supplier Involvement and Knowledge Protection on Product Innovation in Customer-Supplier Relationships: A Study of Global Automotive Suppliers in China
}

\author{
Ruey-Jer 'Bryan' Jean • Rudolf R. Sinkovics • Thomas Hiebaum
}

\section{This is a pre-print (post-peer review \& non-publisher's document). Please cite the article in press as:}

Jean, Ruey-Jer 'Bryan', Rudolf R. Sinkovics, and Thomas Hiebaum (2013), "The effects of supplier involvement and knowledge protection on product innovation in customersupplier relationships: A study of global automotive suppliers in China," Journal of Product Innovation Management, accepted for publication and forthcoming. (available: http://www.manchester.ac.uk/escholar/uk-ac-man-scw:180521 ).

\section{Abstract and Key Results}

- Globalization drivers push firms to develop product innovation through their global supply chains. While innovations generated by supply channel members, as opposed to individual partners, are playing an increasingly important role in the success of all supply chain partners, there has been limited research on how supply chain relationships cultivate the process of such innovation generation, particularly in emerging markets.

- Correspondingly, this study explores how multinational suppliers can develop adaptive product innovation to create competitive advantage in emerging markets. Drawing on the knowledge-based view and transaction cost economics, this study investigates the influence of supplier involvement and other factors on supplier innovation and performance.

- The results of a survey of 170 multinational automobile suppliers in China provide support for most of the hypotheses. Specifically, supplier involvement in co-design has an inverted U-shaped relationship with product innovation. Furthermore, knowledge protection, trust and technological uncertainty are all found to drive greater product innovation. In addition, the institutional environment moderates the effect of product innovation on performance. Overall, this study enhances our understanding of how MNEs can acquire local knowledge and develop adaptive products in emerging markets.

\section{Key Words}

Product innovation, supplier involvement, institutional environment, automotive industry, emerging market

\section{Authors}

Ruey-Jer 'Bryan' Jean

Assistant Professor of International Business

National Chengchi University, Taiwan

(e-mail: bryan@nccu.edu.tw) 
Rudolf R. Sinkovics ( $\square)$

Professor of International Business

Centre for Comparative \& International Business Research

The University of Manchester, Manchester Business School, UK.

(e-mail: Rudolf.Sinkovics@manchester.ac.uk, Web:

http://www.personal.mbs.ac.uk/rsinkovics )

Thomas Hiebaum

Group Vice President and Managing Director, Hella Fahrzeugteile Austria (e-mail: thomas.hiebaum@hella.com) 
The Effects of Supplier Involvement and Knowledge Protection on Product Innovation in Customer-Supplier Relationships: A Study of Global Automotive Suppliers in China

\section{Authors}

Ruey-Jer 'Bryan' Jean

Assistant Professor of International Business

National Chengchi University, Taiwan

64, Sec.2 Zhi-Nan Road

Taipei, 11605, Taiwan

Phone: +886 (2) 2939309188180

(e-mail: bryan@nccu.edu.tw)

Rudolf R. Sinkovics ( $\square$ Corresponding author)

Professor of International Business

Center for Comparative \& International Business Research

The University of Manchester, Manchester Business School

Booth Street West, Manchester M15 6PB, UK.

(e-mail: Rudolf.Sinkovics@manchester.ac.uk, Web: http://www.personal.mbs.ac.uk/rsinkovics )

Thomas P. Hiebaum

Managing Director

Hella Fahrzeugteile Austria

Fabriksgasse 2, A-7503 Großpetersdorf, Austria

(e-mail: thomas.hiebaum@hella.com)

\section{Biographical sketches}

Ruey-Jer (Bryan) Jean is Associate Professor of International Business at National Chengchi University, Taiwan. He received his PhD from Manchester Business School, The University of Manchester, UK where he also worked as a post-doctoral research fellow. His research focuses on inter-organizational relationship management, with particular focus on online and international contexts. His work has appeared in Journal of International Business Studies, Critical Perspectives of International Business, International Marketing Review and Journal of 
International Marketing, Decision Sciences Journal, International Business Review, Management International Review and other journals.

Rudolf R. Sinkovics is a professor of international business at the Manchester Business School (MBS), University of Manchester, UK, and director of the MBS-CIBER (Center for Comparative and International Business Research). He previously held a number of visiting scholar positions, including Michigan State University, University of Oklahoma, and University of Otago at Dunedin, New Zealand. His research centers on interorganizational governance and the role of ICT, with recent work geared towards rising powers and drivers of economic change. He received his PhD from Vienna University of Economics and Business (WU-Wien), Austria. His work has been published in international business and international marketing journals such as Journal of International Business Studies, Management International Review, Journal of World Business, International Business Review, Journal of International Marketing, and International Marketing Review. Born in Austria, he now lives and works in Manchester, UK.

Thomas P Hiebaum holds a master's degree from Vienna University of Economics and Business (WU-Wien) and a PhD in International Business from The University of Manchester, UK. He is Managing Director of Hella Fahrzeugteile Austria GmbH and Vice President of a global performance unit with the Hella group. Prior to his current engagement, he worked for Hella in Germany and as General Manager of Hella Trading (Shanghai) Co., Ltd., a Hella subsidiary in China. From 2008-2009 he served as Chair of the Automotive Working Group at the European Union Chamber of Commerce in China. His research interests focus on knowledge protection and management, and product innovation within the automotive industry and China.

\section{Running title}

Automotive supplier involvement and knowledge protection 


\title{
The Effects of Supplier Involvement and Knowledge Protection on Product Innovation in \\ Customer-Supplier Relationships: A Study of Global Automotive Suppliers in China
}

\begin{abstract}
Globalization drives firms to develop product innovation through their global supply chains. While innovations generated by supply channel members, as opposed to individual partners, are playing an increasingly important role in the success of all supply chain partners, there has been limited research on how supply chain relationships cultivate the process of such innovation generation, particularly in emerging markets. Correspondingly, this study explores how multinational suppliers can develop adaptive product innovation to create competitive advantage in emerging markets. Drawing on the knowledge-based view and transaction cost economics, this study investigates the influence of supplier involvement and other factors on supplier innovation and performance. The results of a survey of 170 multinational automobile suppliers in China provide support for most of the hypotheses. Specifically, supplier involvement in co-design has an inverted U-shaped relationship with product innovation. Furthermore, knowledge protection, trust and technological uncertainty are all found to drive greater product innovation. In addition, the institutional environment moderates the effect of product innovation on performance. Overall, this study enhances our understanding of how MNEs can acquire local knowledge and develop adaptive products in emerging markets.
\end{abstract}

\section{KEYWORDS}

Product innovation, supplier involvement, institutional environment, automotive industry, emerging market 


\section{The Effects of Supplier Involvement and Knowledge Protection on Product Innovation in Customer-Supplier Relationships: A Study of Global Automotive Suppliers in China}

\section{INTRODUCTION}

In hypercompetitive environments, innovation is considered to be key dimension to a firm's competitive position. It is only recently that companies have begun to develop internal environments conducive to innovation and at the same time cultivate and take advantage of external sources, including supply chain partners, to encourage innovation. While collaboration with external partners can enhance innovation performance, including increasing the speed of development and quality of new products, it also incurs certain risks and challenges for firms. For example, Henke and Zhang (2010) recently showed that customers' exploitation of power and a high level of relationship stress in exchange relationships are detrimental to innovation activities in supply chains. This is particularly salient for international exchange relationships, in which geographical or cultural separation between exchange partners increases coordination costs and business risks, creating significant obstacles to innovation generation in supply chains. In addition, multinational enterprises (MNEs) may face a high level of uncertainty and risk when working with supply chain partners in emerging markets such as China, where legal institutions, including intellectual property rights (IPR) and contracts, provide little governance or protection for firms' innovation outputs. Accordingly, how MNEs can adapt their products and processes to 
respond to and overcome institutional voids in emerging markets has become a critical task in discussions around new product development.

In line with this managerial trend, there has been increasing scholarly interest on innovation generation in interorganizational context. Some important issues has been examined in the context of interfirm innovation: different governance mechanisms such as relationship norms including trust and commitments (Mooi and Frambach, 2012; Roy, Sivakumar, and Wilkinson, 2004), unilateral governance including contract, power (Wang, Bradford, Xu, and Weitz, 2008), behavior and output control (Sivakumar, Roy, Zhu, and Hanvanich, 2011), the impact of alliance portfolio (Cui and O'Connor, 2012) and alliance expertise (Sivakumar et al., 2011) and its impact on global innovation generation. Nonetheless, there are some opportunities for research contributions on interfirm innovation in the current literature.

First, while past research has examined different variables and their links to innovation generation, the results are contradictory. For example, supplier involvement in new product design and development has been identified as a critical factor behind firms' innovation and performance in the supply chain (Ragatz, Handfield, and Scannell, 1997; Wynstra, Von Corswant, and Wetzels, 2010). However, prior literature on the relationship between supplier involvement, and innovation and performance, is mixed. Some studies indicate that supplier 
involvement can facilitate the speed of development and quality of new products and reduce production costs (Lau, Tang, and Yam, 2010; Van Echtelt, Wynstra, Van Weele, and Duysters, 2008). Yet, other research shows that supplier involvement incurs high coordination costs and may require firms to put valuable knowledge at risk of appropriation by exchange partners (Wagner and Hoegl, 2006).

Second, empirical evidence on how different governance mechanisms influence innovation generation in interfirm relationships also reveals mixed findings. Though a stream of research argues that formal governance mechanism such as power and control inhibit innovation (Roy and Sivakumar, 2012), other studies reveals the absence of a significant direct link (Wang et al., 2008). The link between informal governance mechanisms such as relational norm on innovation generation is also equivocal. While long term, trust worthy relationships may reduce transaction and coordination cost which lead to interfirm innovation (Mooi and Frambach, 2012). Other researchers argue that diversity of partner portfolio may offer more creative knowledge and ideas in innovation generation in interfirm relationships (Cui and O'Connor, 2012; Jean, Kim, and Sinkovics, 2012).

Third, the literature suggests that the impact of innovation on firm performance is context-specific (Calantone, Harmancioglu, and Droge, 2010; Rosenbusch, Brinckmann, and 
Bausch, 2011), but empirical evidence on the issue is sparse, particularly in the context of emerging markets (Rubera and Kirca, 2012). The institutional environment plays a crucial role in shaping innovation's influence on firm performance, particularly in emerging markets (Bello, Lohtia, and Sangtani, 2004). For example, legal regulations, such as weak intellectual property protection law, may constrain a firm's ability to conduct innovative activities. Consequently, global trading partners from countries with different legal traditions often find it difficult to craft contracting and ownership elements that provide unequivocal safeguards while motivating firms to engage in investments and activities. Accordingly, the relationship between the institutional environment and innovation in channel relationships can benefit from further empirical investigation.

Finally, another deficiency in the literature is that most studies concentrate on interfirm innovation from the customer's perspective within the supply chain relationship (e.g. Azadegan and Dooley, 2010; Hult, Hurley, Giunipero, and Nichols, 2000). While suppliers have become an increasing source of product and process innovation, very little is known about the implications of innovation for suppliers (Chung and Kim, 2003). 


\section{OBJECTIVES AND CONTEXT OF STUDY}

Against this background, the primary objective of this study is to develop and empirically examine antecedents and performance outcomes of product innovation in customer-supplier relationships. While this article proposes formal hypotheses, the overall theoretical positioning of this article is an exploratory one that contributes to theory building. Hence the "soft-modeling" capabilities of PLS (Ringle, Wende, and Will, 2005; Wold, 1980) are deliberately used as the article is interested in variance-explanation rather than covariance-based SEM. In line with this position, this study explores the moderating effect of the hostility of the legal and institutional environment on the innovation-performance link in channel relationships. Taking the supplier's perspective, the study addresses the following research questions: (1) What are the key drivers of product innovation in customer-supplier relationships? Drawing on the knowledge-based view (KBV) and transaction cost economics (TCE), three firm aspects are identified that influence the process of product innovation. Specifically, the article looks into the organizational (supplier involvement, knowledge protection and trust), and environmental (technological uncertainty) factors that affect product innovation in customer-supplier exchange relationships. (2) How and to what extent does product innovation in a customer-supplier relationship affect the supplier's performance? Drawing from the KBV, this article investigates the value creation of innovation in customer-supplier relationships. (3) Does the institutional 
environment in a customer-supplier relationship influence product innovation outcomes and if so to what extent? Integrating insights from institutional theory (Peng, Wang, and Jiang, 2008), this research investigates the moderating effects of the hostility of the legal and institutional environment in which the customer-supplier relationship is located.

This study takes suppliers as its focal firms and looks at their downstream relationships with business customers. The empirical setting of this article includes customer-supplier relationships between first-tier auto component suppliers (suppliers) and their customers, original equipment manufacturers (OEMs), i.e. the manufacturers of automobiles, in China.

It is important to note that MNE auto makers are still required to operate in the form of an international joint venture (IJV) by law, which force MNEs to enter IJVs when operating in China (Kai and Xilai, 2007). However, the rules which regulate automotive supplying companies have been relaxed beginning in the 1990s. Many MNE suppliers have taken the opportunity to analyze their IJVs strategically and convert them into wholly foreign owned enterprises (WFOEs) wherever the Chinese partner was identified not be of positive contribution to the venture, while maintaining the EJV structure wherever the Chinese partner was identified as beneficial to the collaborative arrangements. 
The focus of this study is on the flow of knowledge from a first-tier MNE supplier, either a WFOE or an international joint venture (IJV) to a Chinese automotive OEM.

First-tier MNE auto suppliers- Chinese OEMs customer relationships offer an excellent setting for this study for the following reasons: (a) China is the largest and still the world's fastest-growing auto market. MNE auto makers including vehicles assemblers and components suppliers have strived to enter the Chinese market. For example, General Motors (GM), Ford, PSA, Daimler, Renault, Hyundai, Toyota, Nissan, Honda and Volkswagen (VW), have established joint ventures with Chinese OEMs. In order to earn approval for entering China, MNEs must commit to bring in modern product and process technologies and help develop indigenous R\&D capabilities with their Chinese OEMs at their local operations (Townsend et al., 2010). Accordingly, performing this type of task requires of large extents of supplier involvement with Chinese OMEs among functions such as design, manufacturing, prototyping and testing. (b) For MNEs, emerging market environment involves new firms and institutions within complex and dynamic settings. New product development is a critical and particularly challenging task for MNEs in order to create the need for greater local responsiveness in their host countries' markets. Multinational subsidiaries and joint ventures in the Chinese automotive industry have tried to adapt existing product designs to the local conditions, regulations and consumer tastes. Accordingly, the unique empirical setting of this study provides a good Page 10 of 56 
opportunity to investigate the product innovation process under volatile institutional environment.

This study contributes to the existing knowledge in three ways. First, this study responds to the call for more empirical research on innovation in the context of supply chains (Roy and Sivakumar, 2010; Roy et al., 2004). Second, this study systematically integrates different theoretical lens and empirically test a model which related drivers and outcomes of innovation generation for suppliers in interorganizational context. Third, this study explores the moderating effects of the hostility of the legal and institutional environment in China, on the relationship between product innovation and firm performance in exchange relationships. Thus, this study attempts to make a solid contribution regarding the impact of institutional environments in emerging markets, in shaping firms' innovation strategies.

\section{THEORY AND HYPOTHESES}

Relying on the definition of Eisenhardt and Tabrizi (1995) and Wang et al. (2008), product innovation in customer-supplier relationships in this study refers to the rate of generating novel and improving products from collaborative interorganizational relationships. This study primarily focuses on incremental product innovation, in terms of the adaptation and improvement of the current product and components, in response to a changing environment. 
This is because MNEs' R\&D activities in emerging markets are mostly based at the final stage of the R\&D cycle, involving tasks such as adapting the general design to the local environment (Zhao and Anand, 2009). The design adaptation/localization process requires varying degrees of local knowledge, and, in the case of the automotive industry, could range from extending the length of the car to redesigning the exterior and interior and fitting a new engine. For example, GM-Shanghai made 600 engineering changes to tailor the Buick Century to Chinese driving conditions and regulations (Zhao, An, and Mitchell, 2005).

This study identifies different antecedents of product innovation for MNE suppliers in relationships with Chinese OEMs. According to the TCE, firms manage and safeguard transactional hazards in exchange relationships through employing different interorganizational governance mechanisms including formal and information approaches. The KBV argues that firm knowledge, which is valuable, rare, and inimitable, is the source of a firm's competitive advantage. Because crucial knowledge often resides outside firm boundaries, firms often need to acquire or create new knowledge through external collaborations with different partners. Firms in collaborative relationships can access complementary knowledge bases and thus increase innovation outcomes in exchange relationships. (Grant and Baden-Fuller, 2004). 
Integrating the TCE and the RBV, firms can employ different governance mechanism to safeguard transaction hazards and minimize opportunism in the exchange relationship, which can create an exchange environment facilitating learning and reducing knowledge appropriation, which in turn, can develop better innovation performance. Specifically, this examines three governance mechanism including knowledge protection, supplier involvement and trust and their interrelationships with innovation generation in the exchange relationship. Knowledge protection can be seen as a formal governance mechanism which emphasize minimizing knowledge appropriation via formal standard such as patents, trade secrets etc. Supplier involvement and trust are two information governance mechanisms which are characterized by governing transactional hazards through relational norms.

Accordingly, as shown in Figure 1, following the emerging stream of research on the integration of governance and capabilities perspectives (Bosch-Sijtsema and Postma, 2009; Williamson, 1999), the current study discusses how MNE suppliers can develop innovative capabilities through involvement in co-designing with their Chinese OEMs, but also safeguard against opportunism through knowledge protection and trust building.

In terms of innovation-performance relationships, the literature offers conflicting results. While some studies show that innovation generation is beneficial for firm performance (e.g. Han, 
Kim, and Srivastava, 1998), others find no relationship or even a negative impact on financial performance (Hauser, Tellis, and Griffin, 2006). Based on the KBV, this study argues that product innovation is the process of the integration and creation of new knowledge, which can enhance firm performance in customer-supplier relationships (Menguc and Auh, 2006).

In addition, institutional environment has been argued to play a central role in shaping innovation in supply chain management (Tangpong, Michalisin, and Melcher, 2008). According to the emerging 'institutional theory', institutions constitute regulative, normative and cognitive structures, and engage in activities which can provide stability and meaning to social behavior (Scott, 2008). Previous research suggests that institutional theory can be applied to the investigation of firms' strategic behaviors, particularly in emerging markets (Peng, 2003; Peng et al., 2008). However, empirical evidence on applying institutional theory to examine firms' innovation behavior is still limited. Hence, as shown in Figure 1, we base on institutional theory and argue that legal and institutional hostility can moderate the link between product innovation and performance in the context of interfirm relationships in China.

Insert Figure 1 here 


\section{The influence of supplier involvement on product innovation}

Supplier involvement refers to the extent to which a supplier is involved in co-designing and new product development processes with their customers in exchange relationships (Petersen, Handfield, and Ragatz, 2003). Supplier involvement in new product development has been documented as an important factor behind successful innovation through interfirm cooperation. This is particularly salient in the automotive industry, in which assemblers involve their first-tier suppliers early on in the co-design and co-development of product development processes (Liker, Kamath, Nazli Wasti, and Nagamachi, 1996; Takeishi, 2001).

Prior literature has identified some potential benefits of supplier involvement in a new product, for both manufacturers and their suppliers. For example, some research suggests that supplier involvement can reduce lead times and the risks involved in product development. It can also enhance flexibility and product quality for manufacturers (Lau et al., 2010; Liker et al., 1996). From the supplier's point of view, research also shows that supplier involvement is beneficial for their innovation, product quality and financial performance (Chung and Kim, 2003). From the KBV and organizational learning perspectives, supplier involvement in the form of co-design can facilitate knowledge sharing and learning between suppliers and their customers in exchange relationships (Lakshman and Parente, 2008). The extant literature has shown that there are different types of interfirm collaboration arrangements and ways of facilitating 
knowledge sharing and innovation (Carayannopoulos and Auster, 2010; Tsai, 2009). For MNE automotive part suppliers, becoming involved in co-designing with Chinese assemblers can enhance their local market knowledge base which can help them to adapt their products, access promotion channels, select market segments and upgrade their technology to suit local markets (Tsang, 2002; Zhang, Henke Jr, and Griffith, 2009).

However, the positive effect of supplier involvement in co-design on product innovation in customer-supplier relationships may decline after it reaches a high level for the following reasons. First, with more supplier involvement, more knowledge is shared between MNE suppliers and their Chinese customers. However, the heterogeneity of knowledge among these organizations will decrease. Accordingly, the information and knowledge benefits of supplier involvement decline, which reduces the insights and idea-generation for new product development. The organizational learning literature suggested that high degree of knowledge sharing can actually limit the number of ideas and competencies available for recombining and generating creative approaches. Empirical evidence also shows that knowledge sharing routines have an inverted-U shape relationship with the generation of creative ideas in customer-supplier relationships (Wang et al., 2008). 
In addition, prior literature suggested that firms may become overconfidence and overlook potential opportunities which may lead to product innovation (Petersen, Pedersen, and Lyles, 2008). Organizational learning theory state that perceptions of past success encourages complacency or satisfaction with the status quo, and therefore reduce search efforts and incur superstitious learning, ultimately hamper creativity (Zollo, 2005). In the context of China, MNEs suppliers may generalize and oversimplify learning experience from one Chinese customer and wrongly apply it to all Chinese markets. Hence, the benefits of knowledge and information sharing from supplier involvement may decline, which reduce the idea generation and creativity for product innovation.

Taken together, while supplier involvement in co-design can bring new ideas from Chinese market and customers, when it reaches a high level, its benefits may decline due to the lack of heterogeneous knowledge and overconfidence. Hence,

H1: In customer-supplier relationships in China, there is an inverted U-shaped relationship between a supplier's involvement in co-design and that supplier's product innovation.

\section{The influence of knowledge protection on supplier product innovation}

This study defines knowledge protection as the extent to which firms use certain processes to govern and protect their proprietary knowledge (Nielsen and Nielsen, 2009; Norman, 2002). From the TCE perspective, knowledge protection can be seen as a governance mechanism 
against opportunistic behavior in the exchange relationship. According to this view, firms may use certain knowledge protection processes, such as patents, trademarks and trade secrets, to protect their IP. In addition, firms may routinely ask both employees and customers to sign non-disclosure contracts, that have IP defense clauses clearly mentioned (Roy and Sivakumar, 2011). According to the KBV, knowledge and intellectual property are at the core of the competence of a firm. Integrating the ideas from TCE and the KBV, knowledge protection can serve as a safeguard to facilitate firms' willingness to share more sensitive and implicit knowledge within the new product development process, which, in turn, can drive better product innovation in the exchange relationship. In addition, knowledge protection can codify each party's rights, duties, obligations, and responsibilities, as well as specifying goals, by creating formal operating procedures that require communication and knowledge sharing. Thus, firms that employ appropriate knowledge protection may gain a competitive advantage in interfirm innovation (Zhang et al., 2009).

However, an overemphasis on knowledge protection may be detrimental to trust and teamwork in interfirm relationships. In addition, the development of innovation and creativity requires open and frequent communication and interaction between exchange partners (Roy et al., 2004). Knowledge protection may stifle firms' intentions to share knowledge with their partners and hamper product innovation efforts within such partnerships. 
However, in the context of emerging markets, where legal and formal governance mechanisms do not always work very well, better knowledge protection and IP defense strategies may serve as a means to overcoming institutional voids (Peng, 2003). Thus, we argue that the benefits of knowledge protection for product innovation may outweigh its deficiencies. Based on these arguments, we propose

H2: In customer-supplier relationships in China, knowledge protection is positively related to supplier product innovation.

\section{The influence of trust on supplier product innovation}

In this study, trust is defined as the confidence that exchange parties have in each other's reliability and integrity (Doney and Cannon, 1997; Zhang, Cavusgil, and Roath, 2003). The literature highlights that trust is better at governing cross-border relationships, because physical and cultural distance undermines the ability of a formal contract to identify and cover each contingency (Cavusgil, Deligonul, and Zhang, 2004).

Because trust eases communication between exchange parties, it is perceived as a critical driver of knowledge transfer and acquisition. When trust exists, the exchange parties are more likely to be open and receptive to the knowledge offered by the other party. This intimacy is also associated with frequent communication and flexibility of coordination, because parties are more willing to respond quickly to interfirm requests (Nielsen and Nielsen, 2009). This can lead to 
better knowledge exchange and more innovative idea generation. Extant literature shows that trust can facilitate knowledge sharing in interfirm relationships (Wang et al., 2008).

A major barrier to interfirm knowledge transfer and supplier involvement in innovation is the potential leakage of valuable knowledge. This is particularly important when the knowledge base between the source and the recipient in the exchange relationship is asymmetric. Trust helps overcome this obstacle by establishing a level of predictability and reliability through the accumulation of exchange experiences (Lee, Chen, Kim, and Johnson, 2008), that is, a belief that the partner will not use the knowledge at the focal firm's expense, increases both parties' willingness to share valuable knowledge. In addition, trust can enable greater cooperation between exchange parties and thus foster greater innovation generation. In a trustworthy relationship between a MNE supplier and its OEM customer, the Chinese OEM will be more willing to share its local knowledge with its MNE partner and this will lead to the better adaptation and improvement of its products to respond to local needs. Hence,

H3: In customer-supplier relationships in China, trust is positively related to supplier product innovation.

\section{The influence of technological uncertainty on supplier product innovation}

Technological uncertainty in this study is defined as the extent to which volatility, change, and unpredictability of technology exist in a supplier's cross-border relationships with 
its international customers (Lee et al., 2008). The importance of the organization's environmental context for innovation is generally well acknowledged in the literature (Kimberly and Evanisko, 1981; Souder, Sherman, and Davies-Cooper, 1998). Building on this, the current study further argues that suppliers adopt more innovative actions in order to adapt to, and take advantage of, the opportunities that emerge from the technological uncertainty in supplier-customer relationships. According to the $\mathrm{KBV}$, firms attempt to pursue emerging opportunities so as to establish competitive advantage in rapidly changing environments (Calantone et al., 2010). Such environments lead to the initiation of new product development and innovative behaviors (Calantone, Garcia, and Dröge, 2003). Unpredictable changes in the technological environment quickly render existing technology for a given customer obsolete, resulting in a shorter product life cycle. Technological uncertainty in this study is defined as the extent to which volatility, change, and unpredictability of technology exist in a supplier's cross-border customer-supplier relationships with its international customers (Lee et al., 2008). The importance of the organization's innovation environment is generally well-acknowledged in the literature (Kimberly and Evanisko, 1981; Souder et al., 1998). Building on this, the current study argues that suppliers adopt more innovative actions in order to adapt to, and take advantage of, opportunities that emerge out of the technological uncertainty in supplier-customer relationships. Unpredictable changes in the technological environment quickly render existing 
technology, targeted for a certain customer, obsolete, resulting in a shorter product life cycle. To minimize the threat of obsolescence, firms need to introduce innovations that depart from their existing products, services, and markets. Firms that pursue such innovations can capitalize on changing circumstances by creating new products and services or meeting the needs of emerging markets (Jansen, Van Den Bosch, and Volberda, 2006).

Further, according to the KBV, firms are more likely to acquire technological knowledge to respond to changing markets via rapid product developments (Sullivan and Marvel, 2011). The acquisition of such knowledge can enhance the firms' absorptive capabilities and compress their learning curves, while avoiding the need to expend scarce internal knowledge resources (Autry, Grawe, Daugherty, and Richey, 2010). Some empirical evidence shows that firms can exploit opportunities offered in such a turbulent environment by creating more innovative products and services. (Li and Atuahene-Gima, 2001; Oke, Walumbwa, and Myers, 2012). In the auto industry, Takeishi $(2001,2002)$ claims that under uncertainty, supplier extend their R\&D into OEM's knowledge space to reduce relational uncertainty. Hence, this study predicts:

H4: In customer-supplier relationships in China, technological uncertainty is positively related to supplier product innovation. 


\section{The impact of supplier product innovation on supplier performance}

The link between innovation and performance has been well documented in the extant literature. However, empirical research on the innovation-performance relationship shows controversial results (Rubera and Kirca, 2012; Sood and Tellis, 2009). This article extends the innovation-performance relationships to the customer-supplier context and treat relationship performance in this study as the ultimate outcome variable. A supplier with more innovations should have the ability to create a relationship with its customer that contributes to its market and financial performance. It can provide better product quality or deliver better products and services in a timely manner, which enhances the effectiveness and efficiency of the exchange relationship. It can also gain more business opportunities to work with international customers because its innovations will build its reputation; this in turn will enhance its sales or profits. For example, Volkswagen has collaborated with the Shanghai Automotive Company Ltd (SAIC) in China to develop localized and innovative vehicles and components to help it gain a better relationship performance. The KBV suggests that innovation generation is an outcome of knowledge integration, application and reconfiguration (Grant, 1996), and can lead to sustainable competitive advantage and, eventually, better firm performance.

Accordingly, it can be suspected that MNE suppliers can overall benefit from innovation in working with OEM suppliers in China. However, this effect is largely context dependent. 
Thus, we hypothesize a positive relationship between product innovation and relationship performance, before addressing moderating factors:

H5: In customer-supplier relationships in China, supplier product innovation is positively related to supplier relationship performance.

The moderating effect of the institutional environment on the link between innovation and supplier relationship performance

The impact of the institutional environment on innovation and performance has been documented in the literature (Bello et al., 2004; Peng et al., 2008). Recent work suggests incorporating the institutional environment as a contextual variable to investigate firms' strategic behaviors in emerging markets. In response to this emerging view, this study examines the contingent effect of the hostility of the legal and institutional environment on the innovation-performance link. The hostility of the legal and institutional environment is expected to have a unique influence on firms' innovative behavior in emerging markets. This construct refers to the degree to which the supplier perceives that the environment poses a threat, as characterized by precarious industry circumstances (competition and cycles, for example), severe regulatory violations, and generally unfavorable conditions, beyond the control of the firm (Zhang et al., 2003). Institutional constraints, such as relatively underdeveloped government, legal and financial structures, pose threats such as weak IP protection and dysfunctional competition for MNEs doing business in China. For example, it has been observed that patent 
and copyright violations, broker contracts and agreements and unfair competitive practices have become widespread in China (Peng and Luo, 2000). The IPRs of MNE suppliers linked to product innovation may go unprotected in such a hostile legal environment, making product innovation a highly risky and less profitable strategy. According to the institutional theory (Peng, 2003; Scott, 2008), firms' strategic behaviors are likely to be influenced by institutional constraints, particularly in emerging markets. Thus,

H6: In customer-supplier relationships in China, the positive relationship between supplier product innovation and supplier relationship performance is weaker in more hostile legal and institutional environments.

\section{METHOD}

\section{Unit of analysis}

We selected cross-border relationships between MNE suppliers and their Chinese OEM customers in the Chinese automotive industry as the empirical setting for this study for the following reasons. First, unique knowledge asymmetries exist in this specific interfirm relationship. Before the influx of multinational firms in the mid-1980s, the Chinese automotive industry was far behind the world standard in terms of technological and managerial capabilities. Hence, most of the technical knowledge transfer is moving from MNEs (source) to local Chinese OEMs (receiving organization). The relationships between MNE suppliers and Chinese OEMs are subject to a high degree of relational stress, due to this significant asymmetry in the exchange 
relationship. In addition, China is one of the world's fastest-growing automobile markets. Thus, examining product innovation for MNE suppliers in the Chinese automotive industry could provide managerial and theoretical implications for MNEs' innovation and international strategies in emerging markets. Furthermore, in order to achieve success in Chinese markets in this industry, the most prevalent engineering task that multinational corporations' subsidiaries and joint ventures perform is to adapt existing product designs to the local conditions, regulations, and consumer tastes. Consequently, we can observe large variations in the mechanisms and outcomes of product innovation for MNE suppliers in this setting.

\section{Sampling frame and data collection}

Our study focuses on the relationship dyad between foreign suppliers and their major Chinese OEM customers in the automotive industry in China. Senior product and project managers from MNEs directly involved in international OEM relationships with Chinese customers were chosen as the key informants for this study. A survey methodology was used to collect the data. The sampling frame consisted of MNEs supplying automobile parts, taken from the lists in the directory of China Automobile and Parts (850 companies), which are produced by different nations' chambers of commerce in China. The sample was restricted to MNEs that met the following criteria: (1) for-profit MNEs that are potentially in need of both the technical and managerial know-how of local firms and engage in product innovation in China, (2) MNEs with 
only one foreign parent and (3) wholly foreign-owned or international joint ventures. All firms in the database were contacted to assess their eligibility and to determine appropriate informants for the study. Respondents were asked to specify their most important Chinese customers in terms of largest sales volume.

Data collection was conducted in two stages. In-depth interviews were first conducted with fifteen senior product and project managers or directors of the MNE suppliers. This initial qualitative and exploratory approach provided valuable inputs for the refinement of the questionnaire and the adaptation of the key constructs to the industry context. These interviews served as an a priori test of the key constructs with respect to their usefulness and appropriateness. In the second stage, relevant survey data was collected pursuing approaches including mail, telephone and face-to face interviews. The senior managers involved in the survey answered the questionnaire by choosing their firm's major Chinese OEM customer and responding to all questions with respect to their firm's relationship with that customer.

Of the 850 firms contacted, a total of 170 useable questionnaires were returned, resulting in an effective response rate of $20.0 \%$ (170/850). Among the 170 firms, $49.4 \%$ were joint ventures, and the other $50.6 \%$ were foreign parents of subsidiaries. With regards to nationality, the MNE suppliers in our sample came from various countries or regions, including Germany 
(25.9\%), Korea (12.9\%), the United States (12.3\%), Japan (10\%), France (3.6\%), Switzerland (3.0\%), Sweden $(2.4 \%)$, Canada (1.8\%), the Netherlands (1.8\%), the United Kingdom (1.8\%), Taiwan (1.8\%), Singapore (1.8\%), Spain (1.2\%), Hong Kong (1.2\%), Malaysia (1.2\%) and others. Our sample also included the suppliers of a variety of key automobile parts and components, including brakes $(27.6 \%)$, chassis $(26 \%)$, motor $(25.8 \%)$, general electrics $(23.5 \%)$, clutches (23\%), petrol sensors (20\%), filtration (18.2\%), body (17.6\%), exhaust (15.9\%), lighting (15.3\%), cooling (13.5\%), oil chemicals (8\%), batteries $(8.2 \%)$ and others.

Non-response bias was assessed by classifying the responses into two groups, early respondents and late respondents (Armstrong and Overton, 1977). The possibility of non-response bias was checked by comparing the respondents with the non-respondents in terms of number of employees, sales volume, and age of company. The results of the ANOVA show that there are no statistically significant differences between the respondents and the non-respondents on any of these aspects $(\mathrm{F}=0.63, \mathrm{P}>0.10 ; \mathrm{F}=0.92, \mathrm{P} .0 .10 ; \mathrm{F}=0.77, \mathrm{P}>0.10)$.

A reliable assessment of non-response bias can only be achieved via feedback from the non-respondents themselves. Therefore, a selection of non-respondents was identified and called up via telephone, to obtain explanations for their lack of response. In all cases, the reasons provided were related to time pressures in filling out the questionnaire, the general notion that 
the questionnaire was too demanding and that other requests for feedback had to be prioritized.

These findings imply that non-response bias does not pose a significant threat to the study.

\section{Measurement scales}

Multi-item scales and a seven-point response format were used to operationalize all constructs and variables in the study. The questionnaire was developed in English and translated into Chinese, then back-translated into English by a third party, to confirm that it was an equivalent translation. The measures were adapted from existing studies and refined based on feedback from experienced researchers and practitioners in the area of inquiry.

A five-item scale was used to measure supplier involvement in co-design. The scales were adapted from Lakshman and Ronalod (2008) to measure how early on in the design process suppliers were involved. For knowledge protection, we measured the extent to which the MNE suppliers adopted procedures and processes to protect their proprietary knowledge assets (Kale, Singh, and Perlmutter, 2000; Norman, 2002). These four-item scales were borrowed from Norman (2002) and adapted to the current study.

A five-item scale was used to measure trust; it was taken from Doney and Cannon (1997) and adapted to our context. Trust measures the supplier's perception of the credibility and benevolence of their international customers in its cross-border customer-supplier partnerships. 
Technological uncertainty was conceptualized to capture product complexity, technological innovation, and the rate of technological change in the industry (Celly, Spekman, and Kamauff, 1999). It was adapted from Celly et al.'s (1999) and Jaworski and Kohli's (1993) technological turbulence scales. Product innovation in customer-supplier relationships was operationalized as the supplier's application or utilization of knowledge, measured as modifications and/or innovative improvements to products or processes from customer-supplier relationships (Koufteros, Edwin Cheng, and Lai, 2007; Nielsen and Nielsen, 2009). We focus on the overall product innovation performance in a relationship. We adapted the measure of the hostility of the legal and institutional environment from Zhang et al. (2003). It contains two items to measure the extent to which the manufacturer perceives that the environment poses a threat, as characterized by precarious industry circumstances (competition and cycles, for example), severe regulatory violations, or generally unfavorable conditions beyond the control of the firm. For supplier relationship performance, we adapted three items from Kim et al. (2006) to describe the extent to which the relationship had led to improvements in terms of cost reduction, sales growth and profitability.

We also put firm age and organizational arrangements as two control variables. Firm age is a well-recognized factor in a firm's strategic choices and performance Firm age is measured by the number of years since entering China. Extant literature has highlighted the importance of Page 30 of 56 
entry mode on firm performance (Puck, Holtbrügge, and Mohr, 2009). We classify firms' organizational arrangements into two categories including WFOE and IJV. Organizational arrangement was measured by dichotomous variable, assigning 1 as IJV and 2 as WFOE.

\section{Common method bias assessment}

When a survey method is used to collect data using a single source, common method bias is always a potential threat. Thus, we followed Podsakoff and associates' (2003) steps for limiting and assessing the effects of common method variance. First, scale items were carefully constructed drawing on existing research and using a systematic questionnaire and measure development and refinement process. Second, we guaranteed anonymity to all respondents and urged them to respond to questions as honestly as possible considering that there were no right or wrong answers and results would only be presented to third parties in anonymized and aggregated form. Third, within the questionnaire, items were grouped together within general topic areas and not within conceptual dimensions, i.e. respondents were unable to readily detect which underlying constructs were being measured or guess relationships between predictor and criterion variables. Forth, we used post-hoc methods, namely Harman's one-factor rule and partial correlation, to assess the potential effect of common method bias (Podsakoff and Organ, 1986). The analysis produced seven factors with eigenvalues greater than 1, accounting for $69 \%$ of the variance. Neither a single factor nor a general factor emerged that could account for the 
majority of the covariance in the measures. Fifth, we collected objective performance data on sales growth and turnover from 31 firms in the sample. Correlations between the objective sales growth and turnover indicators and the product innovation measure are $0.406(\mathrm{p}<0.01)$ and 0.35 $(\mathrm{p}<0.01)$, respectively and thus provide good evidence for external validity of the psychometric measures used in the questionnaire.

Therefore, we conclude that common method bias does not pose a major threat to the study (Podsakoff and Organ, 1986).

\section{Measurement model assessment and construct validity}

First, we examined the loadings of individual items with their respective constructs (see Table 1). All items with loadings above 0.5 were retained and most of the factor loadings for the measures exceed the threshold level of 0.7, recommended by Fornell and Larcker's (1981a). Second, we examined Cronbach's alpha and the composite reliability values for each of the latent constructs. Both measures suggest reasonable reliability, with all values exceeding the 0.7 threshold (Nunnally and Bernstein, 1994). Table 1 reports the measures used, their respective item loadings, and the construct reliabilities.

Convergent validity was assessed using average variance extracted (AVE) (see Table 2), as suggested by Fornell and Larcker (1981b). Convergent validity was found to be satisfactory as 
all the values are greater than 0.5 (Henseler, Ringle, and Sinkovics, 2009). We further checked discriminant validity using two methods, the Fornell-Larcker criterion (1981b) and the cross-loadings of items. For each variable, the AVE is higher than its highest squared correlation with any other measure, thus we can assume an adequate level of discriminant validity. This is supported by the cross-loadings. The loading of each indicator is greater than all of its cross-loadings (Henseler et al., 2009). Thus, all of these analyses indicate that the data are robust, and well within acceptable ranges.

Insert Table 1 and Table 2 here

\section{Structural model assessment}

After ensuring that the outer model is both reliable and valid, we examined the inner path model using SmartPLS (Ringle et al., 2005). The explanatory power of a partial least squares (PLS) model is determined by the amount of variance explained $\left(\mathrm{R}^{2}\right)$ by the endogenous latent variables (Henseler et al., 2009). The $\mathrm{R}^{2}$ value for relationship performance is 0.385 . While Chin (1998) sets thresholds of $0.67,0.33$, and 0.19 for substantial, moderate, and weak inner path models respectively, Henseler et al. (2009) suggest that a "moderate" $\mathrm{R}^{2}$ value is acceptable if an endogenous latent variable is explained by only one or two exogenous latent variables. To this end, our results can be seen as relevant and indicatory for future research as the prediction capability of 
the model is sufficiently high. We also checked for prediction capability of the model, and used Stone-Geisser's $\mathrm{Q}^{2}$, as suggested in Henseler et al. (2009), applying the blindfolding technique (Tenenhaus, Vinzi, Chatelin, and Lauro, 2005).

\section{ANALYSIS AND RESULTS}

To examine our hypotheses we used proceeded with the use of SmartPLS (Ringle et al., 2005). The choice of PLS over more traditional based forms of structural equation modeling was based on philosophical and theoretical grounds. With this article we pursue an exploratory goal. While we are developing and testing formal hypotheses, the overall theoretical positioning of this article is to contribute to theory building. We thus deliberately use the "soft-modeling" capabilities of PLS (Hair, Sarstedt, Ringle, and Mena, 2011; Ringle et al., 2005; Wold, 1980) and are interested in variance-explanation rather than covariance-based SEM (Hair, Ringle, and Sarstedt, 2011). Additionally, PLS offers two further operational advantages for this study. First, it is suitable for the analysis of relatively small samples. Second, it provides a conveniently strong test of moderation, because it analyzes moderated relationships using continuous integration terms, by multiplying the indicators of the interacting factors, rather than through a comparison of dichotomized groups (Chin, Marcolin, and Newsted, 2003). We use the bootstrapping method to ascertain the stability and significance of the parameter estimates. Table 3 and Table 4 report the beta coefficient and t-value for each hypothesized path, as well as the 
variance explained for each endogenous construct, and summarizes the results by path and hypothesis for each test.

The results reported in Tables 3 and 4 reveal that the estimates of the model parameters are good. These results suggest that the relationships hypothesized in our model (see Figure 1) regarding product innovation strategies of MNE suppliers are sound and empirically supported.

With respect to testing specific hypotheses, in Hypothesis 1, we maintained that a supplier's involvement in co-design would have an inverted U-shaped relationship with product innovation. According to the results, the coefficient of supplier involvement in co-design is positive and significant, with $\mathrm{b}=0.454(\mathrm{p}<0.01)$. In addition, the coefficient of the squared term of supplier involvement in co-design is negative and significant, with $b=-0.385(p<0.01)$. Thus, Hypothesis 1 is supported. In Hypothesis 2, we proposed that a supplier's knowledge protection enhances its product innovation. The results lend support to this hypothesis, with $b=0.137$ $(\mathrm{p}<0.1)$. Regarding the role of trust, we suggested in Hypotheses 3 that trust results in improvements in product, which the results support, with $b=0.253(\mathrm{p}<0.05)$. Hypothesis 4 states that technological uncertainty has a positive impact on supplier innovation generation, which is supported by the results, with $\mathrm{b}=0.267(\mathrm{p}<0.01)$. Hypothesis 5 proposes that supplier product 
innovation generation positively influences relationship performance. The results again provide support for this, with $b=0.588(\mathrm{p}<0.01)$.

In terms of the moderating effects, we expected that a highly hostile legal and institutional environment would decrease the effects of supplier product innovation on relationship performance, as stated in Hypothesis 6. The results show that the interaction between hostility of legal and institutional environment, on the one hand, and product innovation and relationship performance on the other, is significant and negative, with $b=-0.192(p<0.1)$. As a result, Hypothesis 6 is supported.

In addition, we do not find firm age has a significant impact on firm relationship performance. However, the results show that MNE suppliers perform international joint ventures have better performance than wholly own subsidiaries, with $b=-0.07(p<0.1)$.

\author{
Insert Table 3 here
}

\title{
DISCUSSION
}

With the increase in global innovation outsourcing and a significant shift towards supplier-driven innovation networks and open innovation, suppliers are now playing key roles in innovation generation in global supply chains. In the global automotive industry, multinational suppliers have shifted their global production to emerging markets such as China, in order to take 
advantage of high growth opportunities. However, the institutional constraints in emerging markets pose a threat to the MNEs conducting business there. In order to cope with drastic changes in market conditions and regulatory treatments in China, MNEs have to develop successful product innovation strategies. This study investigates how MNE automotive component suppliers can enhance product innovation in customer-supplier relationships with Chinese OEM customers and enhance their relationship performance. In addition, we explore how the institutional environment shapes the outcomes of product innovation. Drawing on TCE and the KBV, this study develops and empirically tests an integrative model that delineates the antecedents and performance outcomes of supplier product innovation in customer-supplier relationships in China. Further, this study applies institutional theory to examine the moderating effect of supplier dependence on the links between drivers and innovation and between innovation and performance. This study broadens and deepens our understanding of how innovation by suppliers can be generated in customer-supplier relationships in emerging markets and how it increases the competitiveness of these suppliers. Below, we discuss the results of this study.

\section{Drivers of innovation generation}

Prior researchers have investigated the impact of supplier involvement in product development, on firm innovation. However, the extant literature provides contradictory results. 
While some work shows that suppliers' involvement in design and product development contributes to higher product quality and product innovation, others do not find a significant effect. Using unique data from MNE automobile component suppliers in China, the results of this study demonstrate that supplier involvement in the co-design process has an inverted U-shaped relationship with product innovation in emerging markets. The findings imply that supplier involvement in co-design with their customers can be beneficial for suppliers, through knowledge sharing and creation. However, the co-design process incurs a risk of knowledge leakage, exacerbated by insufficient legal protection in emerging markets, with local partners often leaking foreign partners' knowledge to other local firms. Accordingly, we argue that the risks of knowledge leakage and the costs of overcoming the protective mindset of local partners may limit the effective flow and integration of foreign partners' knowledge.

Drawing on TCE, the findings also demonstrate that firms need to craft certain governance mechanisms, including knowledge protection and trust building, in the product innovation process. While prior work has suggested that knowledge protection may be detrimental to product innovation because it hinders knowledge sharing (Nielsen and Nielsen, 2009), we argue, and our results confirm, that knowledge protection can help innovation generation in emerging markets, by providing an effective platform for knowledge sharing within the process of interfirm innovation. In emerging markets whose legal systems do not play Page 38 of 56 
a sufficient role in protecting IP, firms need to be more proactive in developing knowledge protection processes to encourage knowledge transfer and creation and, in turn, product innovation. Our findings contribute to this stream of research by demonstrating the role of knowledge protection in facilitating product innovation in emerging markets.

Trust also plays a crucial role in building governance mechanisms for knowledge sharing and product innovation in exchange relationships. The results show that trust has a stronger impact on product innovation than knowledge protection does. Trust results in greater transparency regarding local market intelligence, such as local customer tastes and local government regulations. Thus, it provides the MNE suppliers with the opportunity to gain access to local market knowledge, which ultimately enhances creativity and the development of innovative products. In a study of exporters dealing with foreign distributors, Wu et al. (2007) found that trust plays the most important role in governing international channel relationships and developing local market competence. Our findings lend some support to this view.

We further demonstrate that technological uncertainty may actually enhance supplier innovation, and that an unpredictable and changing technological environment provides an ideal learning platform through which firms can identify emerging market opportunities and discover niche market segments. This finding agrees with the results of earlier organizational innovation 
research, which suggested that environmental uncertainties shape innovation (Damanpour, 1991;

Frambach and Schillewaert, 2002). These results confirm the importance and value of supplier-driven innovation in the presence of frequent technological changes and updates in an industry.

\section{Outcomes of innovation generation}

The results of this study show that supplier product innovation can enhance relationship performance. This finding sheds light on the link between innovation and performance in exchange relationships. Supplier innovation, following the logic of the KBV, is regarded as a critical organizational resource and capability which can drive firm value in interfirm relationships. This finding provides empirical evidence of the link between innovation and performance in the context of interfirm relationships. The results suggest that a creative firm can meet the changing needs of its customers by generating highly innovative and superior products and processes, which, in turn, enhance its relationship performance.

\section{The role of institutional environment in emerging markets}

In response to the emerging theme of integrating institutional theory as a contextual variable into the study of firms' strategic behavior, this research discusses the contingent effect of the hostility of the legal and institutional environment on MNEs' product innovation strategies. 
The results show that the degree of hostility in the legal and institutional environment shapes the effect product innovation has on relationship performance. When MNEs face high hostility in emerging markets, product innovation strategies become more risky and challenging. This is due to a lack of sufficient protection for innovative outputs, which, in turn, hinders product innovation. The results highlight the importance of institutional environment in shaping the development of product innovation strategies in global supply chains (Bello et al., 2004). In a study of new Chinese ventures, Li and Atuahene-Gima (2001) suggest that dysfunctional competition may curb product innovation. While their empirical work does not support their claims, our findings do lend empirical support to this view.

\section{Managerial implications}

This research offers further insights to managers. It demonstrates how MNE suppliers can develop product innovation as an adaptive strategy, in response to uncertainties in emerging markets. The volatile and growing environment in emerging markets offers great opportunities for MNEs but also poses threats, due to underdeveloped infrastructure. The results of this study show that MNE automotive component suppliers can achieve better relationship performance by developing better product innovation strategies. This process requires the involvement of the supplier in the co-design process, the use of knowledge protection and grasping the opportunities presented by technological uncertainties. 
However, managers need to be cautious concerning the risk of knowledge leakage and the potentially protective mindsets of their partners. Institutional constraints, such as dysfunctional competition and IPR issues, in emerging markets may exacerbate these risks. Accordingly, MNEs need to deploy appropriate governance mechanisms to minimize transaction costs while maximizing value creation. Instead of knowledge protection processes, such as patents and contracts, trust building may serve as a better strategy for MNEs to govern their relationships with partners from emerging markets. Trust can serve as one form of bilateral governance, by creating shared beliefs and mutual concern for long-term benefits. Trust helps to create an environment in which MNEs can share local knowledge and thus can drive product innovation in emerging markets.

\section{LIMITATIONS AND FURTHER RESEARCH}

The results of this study should be interpreted in the light of several inherent limitations. First, supplier innovation was measured using subjective measurement and focused on product and process innovation only. Future studies should also include objective measures of supplier innovation, such as patents or R\&D expenditure. In addition, prior studies show that different conceptualizations may have different antecedents and outcomes. Hence, future research may examine other innovation types, such as radical innovation, or technological versus 
administrative innovation, and identify their antecedents and effects on performance in the supply chain.

In terms of methodology, this study relies on data collected from MNE suppliers in the automotive industry. Due to the limited scope of this sample, it is difficult to generalize our findings to other international customer-supplier relationships, especially in other industrial contexts. Future research should thus consider obtaining data from other industries, and both customers and their suppliers, to cross-check the validity of the proposed model. Furthermore, this study adopts only a single respondent strategy, which may potentially produce common method bias. While we have carefully assessed such possible bias, future research should collect data using multiple respondents for each organization in question.

Another limitation of this study is its cross-sectional design. Although the results reveal the drivers and performance outcomes of supplier product innovation, their causality is only implied. Future studies could overcome this limitation using longitudinal data collection, even over relatively short periods.

\section{CONCLUSION}

Global competition is increasingly defining business. Understanding how to acquire local knowledge and develop adaptive products in emerging markets represents a critical 
challenge for MNEs. Our research informs this intriguing topic by showing how supplier involvement, knowledge protection, trust and technological uncertainty influence the product innovation by MNE automobile component suppliers in China. We hope that further research will contribute further by continuing to explore this important issue.

\section{REFERENCES}

Armstrong, J. Scott and Terry S. Overton. 1977. "Estimating nonresponse bias in mail surveys." Journal of Marketing Research 14 (3): 396-402.

Autry, Chad W., Scott J. Grawe, Patricia J. Daugherty and R. Glenn Richey. 2010. "The effects of technological turbulence and breadth on supply chain technology acceptance and adoption." Journal of Operations Management 28 (6): 522-536.

Azadegan, Arash and Kevin J. Dooley. 2010. "Supplier innovativeness, organizational learning styles and manufacturer performance: An empirical assessment." Journal of Operations Management 28 (6): 488-505.

Bello, Daniel C., Ritu Lohtia and Vinita Sangtani. 2004. "An institutional analysis of supply chain innovations in global marketing channels." Industrial Marketing Management 33 (1): 57-64.

Bosch-Sijtsema, Petra M. and Theo J. B. M. Postma. 2009. "Cooperative innovation projects: Capabilities and governance mechanisms." Journal of Product Innovation Management 26 (1): 58-70.

Calantone, Roger, Rosanna Garcia and Cornelia Dröge. 2003. "The effects of environmental turbulence on new product development strategy planning." Journal of Product Innovation Management 20 (2): 90-103.

Calantone, Roger J., Nukhet Harmancioglu and Cornelia Droge. 2010. "Inconclusive innovation "returns": A meta-analysis of research on innovation in new product development." Journal of Product Innovation Management 27 (7): 1065-1081.

Carayannopoulos, Sofy and Ellen R. Auster. 2010. "External knowledge sourcing in biotechnology through acquisition versus alliance: A kbv approach." Research Policy 39 (2): 254-267. 
Cavusgil, S. Tamer, Seyda Deligonul and Chun Zhang. 2004. "Curbing foreign distributor opportunism: An examination of trust, contracts, and the legal environment in international channel relationships." Journal of International Marketing 12 (2): 7-27.

Celly, Kirti Sawhney, Robert E. Spekman and John W. Kamauff. 1999. "Technological uncertainty, buyer preferences and supplier assurances: An examination of Pacific rim purchasing arrangements." Journal of International Business Studies 30 (2): 297-310.

Chin, Wynne W. 1998. "The partial least squares approach to structural equation modelling." In Modern methods for business research. George A. Marcoulides (ed.), 295-358. Mahwah, NJ: Lawrence Erlbaum Associates.

Chin, Wynne W., Barbara L. Marcolin and Peter R. Newsted. 2003. "A partial least squares latent variable modeling approach for measuring interaction effects: Results from a monte carlo simulation study and an electronic-mail emotion/adoption study." Information Systems Research 14 (2): 189-217.

Chung, Seungwha and Gyeong Mook Kim. 2003. "Performance effects of partnership between manufacturers and suppliers for new product development: The supplier's standpoint." Research Policy 32 (4): 587-603.

Cui, Anna S. and Gina O'Connor. 2012. "Alliance portfolio resource diversity and firm innovation." Journal of Marketing: accepted and forthcoming.

Damanpour, Fariborz. 1991. "Organizational innovation: A meta-analysis of effects of determinants and moderators." Academy of Management Journal 34 (3): 555.

Doney, Patricia M. and Joseph P. Cannon. 1997. "An examination of the nature of trust in buyer-seller relationships." Journal of Marketing 61 (2): 35-51.

Eisenhardt, Kathleen M. and Behnam N. Tabrizi. 1995. "Accelerating adaptive processes: Product innovation in the global computer industry." Administrative Science Quarterly 40 (1): 84-110.

Fornell, Claes and David F. Larcker. 1981a. "Evaluating structural equation models with unobservable variables and measurement error." Journal of Marketing Research 18 (1): $39-50$.

Fornell, Claes and David F. Larcker. 1981b. "Structural equation models with unobservable variables and measurement error: Algebra and statistics." Journal of Marketing Research 18 (3): 382-388.

Frambach, Ruud T. and Niels Schillewaert. 2002. "Organizational innovation adoption: A multi-level framework of determinants and opportunities for future research." Journal of Business Research 55 (2): 163-176.

Grant, Robert M and Charles Baden-Fuller. 2004. "A knowledge assessing theory of strategic alliances." The Journal of Management Studies 41 (1): 61. 
Grant, Robert M. 1996. "Prospering in dynamically-competitive environments: Organizational capability as knowledge integration." Organization Science 7 (4): 375-387.

Hair, Joe F., Christian M. Ringle and Marko Sarstedt. 2011. "PLS-sem: Indeed a silver bullet." Journal of Marketing Theory \& Practice 19 (2): 139-152.

Hair, Joe, Marko Sarstedt, Christian Ringle and Jeannette Mena. 2011. "An assessment of the use of partial least squares structural equation modeling in marketing research." Journal of the Academy of Marketing Science 40 (3): 414-433.

Han, Jin K., Namwoon Kim and Rajendra K. Srivastava. 1998. "Market orientation and organizational performance: Is innovation a missing link?" Journal of Marketing 62 (4): $30-45$.

Hauser, John, Gerard J. Tellis and Abbie Griffin. 2006. "Research on innovation: A review and agenda for marketing science." Marketing Science 25 (6): 687-717.

Henseler, Jörg, Christian M. Ringle and Rudolf R. Sinkovics. 2009. "The use of partial least squares path modeling in international marketing." In Advances in international marketing, Vol. 20. Rudolf R. Sinkovics and Pervez N. Ghauri (eds.), 277-319. Bingley: Emerald JAI Press.

Hult, G. Tomas M., Robert F. Hurley, Larry C. Giunipero and Ernest L. Nichols. 2000. "Organizational learning in global purchasing: A model and test of internal users and corporate buyers." Decision Sciences 31 (2): 293-325.

Jansen, Justin J. P., Frans A. J. Van Den Bosch and Henk W. Volberda. 2006. "Exploratory innovation, exploitative innovation, and performance: Effects of organizational antecedents and environmental moderators." Management Science 52 (11): 1661-1674.

Jaworski, Bernard J. and Ajay K. Kohli. 1993. "Market orientation: Antecedents and consequences." Journal of Marketing 57 (3): 53.

Jean, Ruey-Jer "Bryan", Daekwan Kim and Rudolf R. Sinkovics. 2012. "Drivers and performance outcomes of supplier innovation generation in customer-supplier relationships: The role of power-dependence." Decision Sciences 43 (forthcoming): http://decisionsciencesjournal.org/.

Kai, Ma and Bo Xilai. 2007. "Catalogue of encouraged foreign investment industries." Catalogue for the Guidance of Foreign Investment Industries (57): 1-24.

Kale, Prashant, Harbir Singh and Howard Perlmutter. 2000. "Learning and protection of proprietary assets in strategic alliances: Building relational capital." Strategic Management Journal 21 (3): 217-237.

Kim, Daekwan, S. Tamer Cavusgil and Roger J. Calantone. 2006. "Information system innovations and supply chain management: Channel relationships and firm performance." Journal of the Academy of Marketing Science 34 (1): 40-54. 
Kimberly, John R. and Michael J. Evanisko. 1981. "Organizational innovation: The influence of individual, organizational, and contextual factors on hospital adoption of technological and administrative innovations." The Academy of Management Journal 24 (4): 689-713.

Koufteros, Xenophon A., T. C. Edwin Cheng and Kee-Hung Lai. 2007. ""Black-box" and "gray-box" supplier integration in product development: Antecedents, consequences and the moderating role of firm size." Journal of Operations Management 25 (4): 847-870.

Lakshman, C. and Ronaldo C. Parente. 2008. "Supplier-focused knowledge management in the automobile industry and its implications for product performance." Journal of Management Studies 45 (2): 317-342.

Lau, Antonio K. W., Esther Tang and Richard C. M. Yam. 2010. "Effects of supplier and customer integration on product innovation and performance: Empirical evidence in Hong Kong manufacturers." Journal of Product Innovation Management 27 (5): 761-777.

Lee, Ruby P., Qimei Chen, Daekwan Kim and Jean L. Johnson. 2008. "Knowledge transfer between multinational corporations' headquarters and their subsidiaries: Influences on and implications for new product outcomes." Journal of International Marketing 16 (2): $1-31$.

Li, Haiyang and Kwaku Atuahene-Gima. 2001. "Product innovation strategy and the performance of new technology ventures in China." Academy of Management Journal 44 (6): 1123-1134.

Liker, Jeffrey K., Rajan R. Kamath, S. Nazli Wasti and Mitsuo Nagamachi. 1996. "Supplier involvement in automotive component design: Are there really large US Japan differences?" Research Policy 25 (1): 59-89.

Menguc, Bulent and Seigyoung Auh. 2006. "Creating a firm-level dynamic capability through capitalizing on market orientation and innovativeness." Journal of the Academy of Marketing Science 34 (1): 63-73.

Mooi, Erik A. and Ruud T. Frambach. 2012. "Encouraging innovation in business relationships—a research note." Journal of Business Research 65 (7): 1025-1030.

Nielsen, Bo Bernhard and Sabina Nielsen. 2009. "Learning and innovation in international strategic alliances: An empirical test of the role of trust and tacitness." Journal of Management Studies 46 (6): 1031-1056.

Norman, Patricia M. 2002. "Protecting knowledge in strategic alliances: Resource and relational characteristics." The Journal of High Technology Management Research 13 (2): 177-202.

Nunnally, Jum C. and Ira H. Bernstein. 1994. Psychometric theory (3rd ed.). New York: McGraw-Hill. 
Oke, Adegoke, Fred O. Walumbwa and Andrew Myers. 2012. "Innovation strategy, human resource policy, and firms' revenue growth: The roles of environmental uncertainty and innovation performance." Decision Sciences 43 (2): 273-302.

Peng, Mike W. 2003. "Institutional transitions and strategic choices." Academy of Management Review 28 (2): 275-296.

Peng, Mike W. and Yadong Luo. 2000. "Managerial ties and firm performance in a transition economy: The nature of a micro-macro link." Academy of Management Journal 43 (3): 486-501.

Peng, Mike W., Denis Y. L. Wang and Yi Jiang. 2008. "An institution-based view of international business strategy: A focus on emerging economies." Journal of International Business Studies 39: 920-936.

Petersen, Bent, Torben Pedersen and Marjorie A. Lyles. 2008. "Closing knowledge gaps in foreign markets." Journal of International Business Studies 39 (7): 1097-1113.

Petersen, Kenneth J., Robert B. Handfield and Gary L. Ragatz. 2003. "A model of supplier integration into new product development." Journal of Product Innovation Management 20 (4): 284-299.

Podsakoff, Philip M., Scott B. MacKenzie, Lee Jeong-Yeon and Nathan P. Podsakoff. 2003. "Common method biases in behavioral research: A critical review of the literature and recommended remedies." Journal of Applied Psychology 88 (5): 879-903.

Podsakoff, Philip M. and Dennis W. Organ. 1986. "Self-reports in organizational research: Problems and prospects." Journal of Management 12 (4): 531-544.

Puck, Jonas F, Dirk Holtbrügge and Alexander T Mohr. 2009. "Beyond entry mode choice: Explaining the conversion of joint ventures into wholly owned subsidiaries in the people's republic of China." Journal of International Business Studies 40 (3): 388-404.

Ragatz, Gary L., Robert B. Handfield and Thomas V. Scannell. 1997. "Success factors for integrating suppliers into new product development." Journal of Product Innovation Management 14 (3): 190-202.

Ringle, Christian Marc, Sven Wende and Alexander Will. 2005. Smartpls 2.0 m3. Hamburg, Germany: University of Hamburg.

Rosenbusch, Nina, Jan Brinckmann and Andreas Bausch. 2011. "Is innovation always beneficial? A meta-analysis of the relationship between innovation and performance in SMEs." Journal of Business Venturing 26 (4): 441-457.

Roy, Subroto and K. Sivakumar. 2010. "Innovation generation in upstream and downstream business relationships." Journal of Business Research 63 (12): 1356-1363.

Roy, Subroto and K. Sivakumar. 2011. "Managing intellectual property in global outsourcing for innovation generation." Journal of Product Innovation Management 28 (1): 48-62. 
Roy, Subroto and K. Sivakumar. 2012. "Global outsourcing relationships and innovation: A conceptual framework and research propositions." Journal of Product Innovation Management 29 (4): 513-530.

Roy, Subroto, K. Sivakumar and Ian F. Wilkinson. 2004. "Innovation generation in supply chain relationships: A conceptual model and research propositions." Journal of the Academy of Marketing Science 32 (1): 61-79.

Rubera, Gaia and Ahmet H. Kirca. 2012. "Firm innovativeness and its performance outcomes: A meta-analytic review and theoretical integration." Journal of Marketing 76 (3): 130-147.

Scott, W. Richard. 2008. Institutions and organizations: Ideas and interests (3rd ed.). Thousand Oaks, CA: Sage Publications.

Sivakumar, K., Subroto Roy, JianJun Zhu and Sangphet Hanvanich. 2011. "Global innovation generation and financial performance in business-to-business relationships: The case of cross-border alliances in the pharmaceutical industry." Journal of the Academy of Marketing Science 39 (5): 757-776.

Sood, Ashish and Gerard J. Tellis. 2009. "Do innovations really pay off? Total stock market returns to innovation." Marketing Science 28 (3): 442-456.

Souder, William E., J. Daniel Sherman and Rachel Davies-Cooper. 1998. "Environmental uncertainty, organizational integration, and new product development effectiveness: A test of contingency theory." Journal of Product Innovation Management 15 (6): 520-533.

Sullivan, Diane M. and Matthew R. Marvel. 2011. "Knowledge acquisition, network reliance, and early-stage technology venture outcomes." Journal of Management Studies 48 (6): 1169-1193.

Takeishi, Akira. 2001. "Bridging inter- and intra-firm boundaries: Management of supplier involvement in automobile product development." Strategic Management Journal 22 (5): 403-433.

Takeishi, Akira. 2002. "Knowledge partitioning in the interfirm division of labor: The case of automotive product development." Organization Science 13 (3): 321-338.

Tangpong, Chanchai, Michael D. Michalisin and Arlyn J. Melcher. 2008. "Toward a typology of buyer-supplier relationships: A study of the computer industry." Decision Sciences 39 (3): 571-593.

Tenenhaus, Michel, Vincenzo Esposito Vinzi, Yves-Marie Chatelin and Carlo Lauro. 2005. "PLS path modeling." Computational Statistics \& Data Analysis 48 (1): 159-205.

Townsend, Janell D., S. Tamer Cavusgil and Marietta L. Baba. 2010. "Global integration of brands and new product development at general motors." Journal of Product Innovation Management 27 (1): 49-65. 
Tsai, Kuen-Hung. 2009. "Collaborative networks and product innovation performance: Toward a contingency perspective." Research Policy 38 (5): 765-778.

Tsang, Eric W. K. 2002. "Acquiring knowledge by foreign partners from international joint ventures in a transition economy: Learning-by-doing and learning myopia." Strategic Management Journal 23 (9): 835-854.

Van Echtelt, Ferrie E. A., Finn Wynstra, Arjan J. Van Weele and Geert Duysters. 2008. "Managing supplier involvement in new product development: A multiple-case study." Journal of Product Innovation Management 25 (2): 180-201.

Wagner, Stephan M. and Martin Hoegl. 2006. "Involving suppliers in product development: Insights from R\&D directors and project managers." Industrial Marketing Management 35 (8): 936-943.

Wang, Qiong, Kevin Bradford, Jun Xu and Barton Weitz. 2008. "Creativity in buyer-seller relationships: The role of governance." International Journal of Research in Marketing 25 (2): 109-118.

Williamson, Oliver E. 1999. "Strategy research: Governance and competence perspectives." Strategic Management Journal 20 (12): 1087-1108.

Wold, Hermann. 1980. "Soft modelling: Intermediate between traditional model building and data analysis." Mathematical Statistics 6: 333-346.

Wu, Fang, Rudolf R. Sinkovics, S. Tamer Cavusgil and Anthony S. Roath. 2007. "Overcoming export manufacturer's dilemma in international expansion." Journal of International Business Studies 38 (2): 283-302.

Wynstra, Finn, Fredrik Von Corswant and Martin Wetzels. 2010. "In chains? An empirical study of antecedents of supplier product development activity in the automotive industry." Journal of Product Innovation Management 27 (5): 625-639.

Zhang, Chun, S. Tamer Cavusgil and Anthony S. Roath. 2003. "Manufacturer governance of foreign distributor relationships: Do relational norms enhance competitiveness in the export market?" Journal of International Business Studies 34 (6): 550-566.

Zhang, Chun, John W. Henke Jr and David A. Griffith. 2009. "Do buyer cooperative actions matter under relational stress? Evidence from Japanese and U.S. Assemblers in the U.S. Automotive industry." Journal of Operations Management 27 (6): 479-494.

Zhao, Jane Zheng and Jaideep Anand. 2009. "A multilevel perspective on knowledge transfer: Evidence from the Chinese automotive industry." Strategic Management Journal 30 (9): 959-983.

Zhao, Zheng, Jaideep An and Will Mitchell. 2005. "A dual networks perspective on inter-organizational transfer of R\&D capabilities: International joint ventures in the Chinese automotive industry." Journal of Management Studies 42 (1): 127-160. 
Zollo, Maurizio. 2005. "Superstitious learning revisited: Outcome ambiguity and confidence traps in corporate acquisitions." CIFS Centre for International Financial Service Working Paper 68/ST/CIFS: 1-46. 
Table 1: Measures and Composite Reliabilities

Construct (Composite Reliability: $\mathrm{CR}_{\eta}$ )

Item (Loading)

Supplier Involvement in Co-design $\left(\mathrm{CR}_{\eta}=\mathbf{0 . 8 4 2}\right)(1=$ strongly disagree; $7=$ strongly agree $)$

My company usually gets involved in the new product development process in an early stage of product design. (0.666)

We have an active role in product design specifications. (0.698)

During the product development stage, there is a high level of involvement between our development team and our major OEM customer. (0.735)

During the product development stage, our major OEM customer often benefits from our expertise and experience. (0.825)

Co-design activity on our product with our OEM customer is a major priority for us. (0.624)

Knowledge Protection $\left(\mathrm{CR}_{\eta}=\mathbf{0 . 8 1 4}\right)(1=$ strongly disagree; $7=$ strongly agree $)$

My company has formal and systemized processes for protecting knowledge, e.g. contracts, regulations and procedures. $(0.682)$

My company relies on patents and trademarks to protect our critical knowledge from inappropriate use. (0.788)

My company has processes to protect knowledge from inappropriate use inside or outside the organization. (0.793)

My company has incentives that encourage the protection of knowledge. (0.623)

Trust $\left(\mathrm{CR}_{\eta}=\mathbf{0 . 8 6 6}\right)$ (1=strongly disagree; $7=$ strongly agree $)$

My company trusts that our automotive OEM customer is able to fulfill contractual agreements. (0.728)

As far as key issues are concerned, our OEM customer is always honest with us. (0.795)

My company believes the information that our OEM customer provides to us. (0.761)

Our OEM customer is genuinely concerned about whether our business succeeds. (0.759) 
When making important decisions, our OEM customer considers our welfare as well as its own. (0.708)

Technological Uncertainty $\left(\mathrm{CR}_{\eta}=\mathbf{0 . 8 1 6}\right)(1=$ strongly disagree; $7=$ strongly agree $)$

Technological changes provide big opportunities in our industry. (0.768)

There is a high level of technological innovation in our industry. (0.787)

More complex products are provided in our industry. (0.761)

Product Innovation in Customer-Supplier Relationships $\left(\mathrm{CR}_{\eta}=\mathbf{0 . 8 5 8}\right)(1=$ strongly disagree; $7=$ strongly agree)

Our relationship with the customer has a positive effect on our ability to make improvements /adaptations to our existing products. (0.819)

Our relationship with the customer has helped lower product return rates on their orders with us. (0.764)

Our relationship with the customer has a positive effect on our ability to develop successful new products for our markets. $(0.761)$

Our relationship with the customer has helped us to achieve a great number of product adaptations/ improvements in the last three years. (0.759)

Relationship performance $\left(\mathrm{CR}_{\eta}=\mathbf{0 . 8 6 3}\right)$ ( 1 =strongly disagree; $7=$ strongly agree $)$

Our relationship with our customer helps to increase sales (0.776)

Our relationship with our customer helps to increase our market share. (0.852)

Our relationship with our customer helps to increase our profitability. (0.839)

Hostility of Legal and Institutional Environment $\left(\mathrm{CR}_{\eta}=\mathbf{0 . 9 2 0}\right)(1=$ strongly disagree; $7=$ strongly agree)

Local companies in China frequently interpret local laws in their favor. (0.898)

Our OEM customers frequently violate local laws in their favor. (0.948) 
Table 2: Intercorrelations and Shared Variances of Measures $(n=170)$

\begin{tabular}{cccccccc}
\hline & F1 & F2 & F3 & F4 & F5 & F6 & F7 \\
\hline Supplier Involvement in Co-design (F1) & .72 & & & & & & \\
Knowledge Protection (F2) & .52 & .72 & & & & \\
Trust (F3) & .25 & .49 & .75 & & & \\
Technological Uncertainty (F4) & .27 & .37 & .44 & .77 & & \\
Product Innovation (F5) & .50 & .38 & .48 & .46 & .77 & \\
Relationship performance (F6) & .47 & .38 & .44 & .40 & .62 & .82 & \\
Hostility of Legal and Institutional & & & & & & & \\
Environment (F7) & .43 & .29 & .40 & .30 & .25 & .27 & .92 \\
& & & & & & \\
Note: & The correlations are shown in the lower triangle of the matrix.. Numbers \\
on the diagonal shown in bold denote the square root of the average \\
variance extracted.
\end{tabular}


Table 3: Test of Hypothesized Relationships: Beta Coefficients and t-values

\begin{tabular}{|ll|}
\hline Independent variables & $\begin{array}{l}\text { Dependent variable } \\
\text { Product innovation }\end{array}$ \\
\hline $\begin{array}{l}\text { Supplier involvement in co-design } \\
\text { Supplier involvement in co-design * Supplier }\end{array}$ & $0.454(2.389)^{* *}$ \\
involvement in co-design & $-0.385(2.380)^{* *}$ \\
Knowledge protection & $0.137(1.810)^{*}$ \\
Trust & $0.253(2.954)^{* * *}$ \\
Technological uncertainty & $0.267(3.501)^{* * *}$ \\
\hline
\end{tabular}

$* \mathrm{P}<0.1, * * \mathrm{P}<0.05, * * * \mathrm{P}<0.01$

Table 4: Test of Hypothesized Relationships: Beta Coefficients and t-values

\begin{tabular}{|ll|}
\hline Independent variables & $\begin{array}{l}\text { Dependent variable } \\
\text { Relationship performance }\end{array}$ \\
\hline Age & 0.038 \\
organizational arrangements & $-0.07 *$ \\
Product innovation in customer-supplier & $0.614(7.72) * * *$ \\
relationships & \\
Product innovation in customer-supplier & $-0.192(1.772)^{*}$ \\
relationships * Hostility of legal and & \\
institutional environment & \\
& \\
\hline
\end{tabular}

$* \mathrm{P}<0.1, * * \mathrm{P}<0.05, * * * \mathrm{P}<0.01$ 
Figure 1: Conceptual Framework

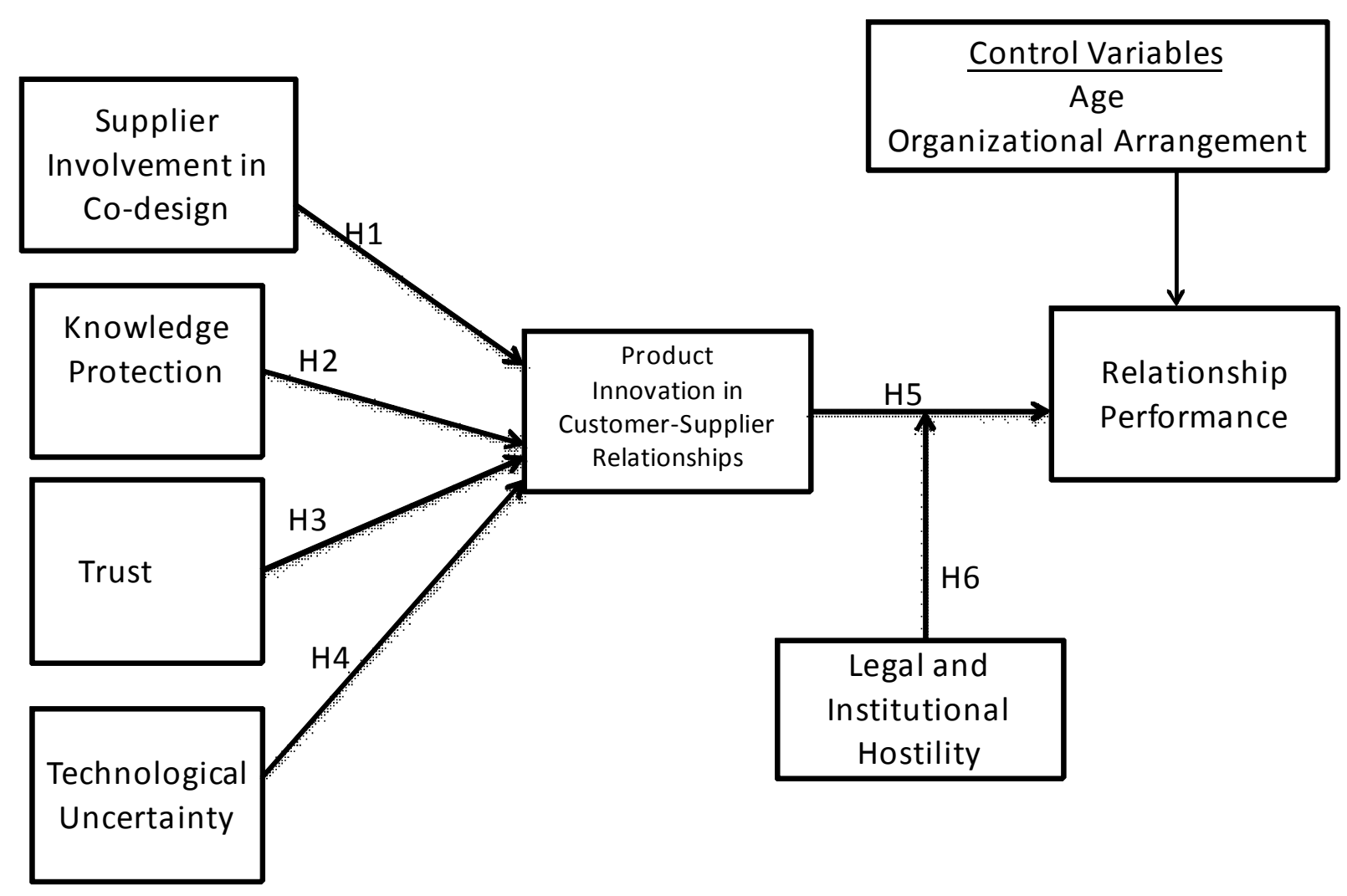

